\title{
BEHAVIOR OF THE ARMY ANT Eciton burchelli WESTWOOD (HYMENOPTERA FORMICIDAE) IN THE BELEM REGION. II. BIVOUACS.
}

\author{
Madalena Teles da Silva \\ Departamento de Biologia da Faculdade de Filosofia, Ciências e Letras de \\ Ribeirão Preto - USP - SP, Brasil.
}

\begin{abstract}
$A B S T R A C T$
This paper is based on studies of $E$. burchelli and $E$. hamatum behavior in the Amazonian forest, carried out along two years. The core is the analysis of $E$. burchelli and $E$. hamatum nesting and their variation in a tropical rain forest.

Several bivouacs were recorded of eight $E$, burchelli colonies and one of E. hamatum. We observed the types of bivouacs locations, bivouac patterns, exposure degree, duration of the nomadic bivouacs and distances between the bivouacs. These characters are related to the colony condition and seasons. A comparison is made between the species studied and also with the data obtained at Barro Colorado Island by other authors.
\end{abstract}

\section{$R E S U M O$}

O trabalho baseia-se em observações feitas sobre o comportamento de Eciton burchelli Westwood e Eciton hamatum Fabricius na região Amazônica, Belém, PA. durante os anos de 1966-1968. O objetivo do presente estudo refere-se ao processo de nidificação de ambas espécies e de suas variações de acordo com o tipo de mata, épocas do ano e condições internas da colônia.

Durante o periodo de estudo fizeram-se as seguintes observações: tipo de locais utilizados para nidificação; padrões dos ninhos ou bivaques; grau de exposição; duração dos bivaques nômades e distância entre os bivaques estabelecidos durante a fase nômade. Estes caracteres foram relacionados com as condições das colônias das espécies estudadas. bem como com as estações do ano. Fizeram-se comparações dos resultados obtidos com os já coletados nor outros autores na Ilha de Barro Colorado, Zona do Canal.

\section{INTRODUCTION}

The Neotropical ants of the tribe Ecitonini share with the Dorylinae of the Paleotropical region a carnivorous diet, a nomadic life cycle and large sized colonies (not below 100,00 individuals to hundreds of thousand or even millions in some species).

Because the diet of army ants consists almost, if not entirely, of the flesh of other animals, these ants present a complex pattern of life in which the capacity of establishing permanent nests has been lost or very extensively modified. The army ant nest or "bivouac" (Schneirla, 1933, 1938) is temporarily formed by the ants own bodies, without the manipulation of foreign materials. 
The studies of the bivouacs as an adaptive factor in the terrestrial species of the army ants $E$. burchelli and $E$. hamatum, were developed at Barro Colorado Island by Schneirla (1933, 1971), Schneirla, Brown and Brown (1954) and Jackson (1957). In these papers detailed discussions of the formation and internal composition of bivoluacs have been published.

According to Schneirla, Brown and Brown (1954), the bivourac is a key factor for the adaptation of the Eciton species to nomadic surface life. These authors also proved that the bivouacs differ strikingly in relation to the activity phase, the nomadic bivouacs being more exposed to the general environmental conditions than the statary ones, which tend to occur within a natural cavity. The internal temperature of the bivouac in both pliases is higher and very less variable than the environmental temperature, and the internal microclimatic condition shows more stability in the statary phase bivouac than in the nomadic phase.

Among the environmental factors affecting terrestrial Eciton species, the relative humidity is perhaps the most crucial. Schneirla (1971) observed that a relative humidity of $50 \%$ or less is lethal for the worker and for the colony also and so the bivouac must provide the colonial microclimate with the necessary adjustments to face the general atmospheric variations.

The present paper is part of a project dealing with $E$. burchelli behavior in the Amazonian forest. These studies were carried out for two years (April 1966 to June 1968) in a forest reserve at the "Instituto de Pesquisa e Experimentação Agropecuárias do Norte" (IPEAN), in Belém, Pará State, Brazil in collaboration with the Smithsonian Institution, Washington. The mentioned reserve was called APEG-Área de Pesquisas Ecológicas do Guamá (Ecological Research Area). For more information about the area (vegetation, annual climate pattern, etc) see Teles da Silva (1975). The core of this paper is the study of $E$. burchelli and $E$. hamatum nesting in a tropical rain forest.

\section{MATERIAL AND METHODS}

An identification code number was applied to each colony and consists of the capital letter $\mathrm{E}$ followed by Arabic numerals. The colonies were observed daily with the aid of a field assistant.

Several hivouacs of $E$. burchelli colonies (E-O, E-1, E-2, E-2A, E-2B, E-3, E-4, E-14) were observed including one of E. hamatum (E-7).* During the observations the following data were recorded: substratum used for the bivouac establishment, colony condition, season, bivouac pattern, relative exposure of bivouacs, bivouac height, duration (hours) of the nomadic bivouac, distances between the bivouacs, etc. The pattern and relative exposure of the bivouac, were described in Schneirla, Brown \& Brown (1954) as follows:

a) Cylindrical (standard type): when the bivoulac cluster tends to be a symmetrical modified cylincier with vertical central axis; the diameter decreasing from top to bottom.

b) Compound: cluster formed among many supporting structures to the ground.

* More details on the studied colonies are in Teles da Silva (in press), Table I. 
c) Curtain: bivouac formed under the side of a tree log, or interbuttress space of a tree. It has a form of "half-cylinder"

d) Plug: the ant cluster closes a cavity of a tree hollow or hollow log.

e) Pouch: the bivouac ceiling is usually far from the ground so that the base of the cluster hangs in midair.

Temperature records of all nomadic bivouacs established during one nomadic phase (duration of 12 days) were taken 51 times for the E-O colony. For the nomadic bivouac temperature records were taken daily at different hours, from $08 \mathrm{AM}$ to $18 \mathrm{PM}$, with 2 hours intervals. The temperature record in each interval is the mean of three sucessive readings. Air temperature was measured just at bivouac level with immersion-type mercury-in-glass thermometers $\left(0-50^{\circ} \mathrm{C}\right)$. The internal and external temperatures of a statary bivouac (E-1 colony) were taken at each 2 hours intervals throughout the 24 hours of the day.

\section{RESULTS}

\section{A. Bivoutac locations}

During the course of the present study $137 E$. burchelli bivouacs and 40 of $E$. hamatum were recorded. From Table $\mathrm{I}$, where the results are summarised, it is ascertained that from $114 \mathrm{E}$. burchelli nomadic bivouacs observed the majority was found beneath $\operatorname{logs}(25 \%)$ and in hollow logs $(32 \%)$. From the 23 statary bivouacs observed $61 \%$ were established in hollow trees and $17 \%$ in hollow logs. In $E$. hamatum the preferred sites for nomadic bivouacs were beneath logs (35\%) and under leaves or tree roots $(41 \%)$. In this species the establishment of statary bivouacs occurred only beneath logs $(50 \%)$ or hollow logs $(50 \%)$.

The above results show the increased plasticity of $E$. burchelli when compared to $E$. hamatum as regards bivouac locations.

\section{B. Bivouac patterns}

The bivouac patterns described by Schneirla, Brown and Brown (1954) are based upon the manner the cluster of ant bodies hangs from a support to the ground. The standard bivouac pattern for $E$. hamatum and E. burchelli colonies is the cylindrical type. But considerable variations occur, mainly related to environmental heterogeneity, colony size and conditions.

For $E$. burchelli colonies the 113 records of nomadic bivouac types demonstrated that the cylindrical pattern is more frequent $(47 \%)$; the other types were recorded in the following frequency: plug $(35 \%)$, compound $(8 \%)$, curtain $(2 \%)$ and pouch $(2 \%)$. For the statary bivouac the common pattern was the plug type since in 23 bivouacs $78 \%$ were of that type, $13 \%$ pouch, $4 \%$ cylindrical and $4 \%$ curtain.

Variations in bivouac patterns were observed and these were found to be seasonal. Table II shows that in the dry season the bivouac patterns are less variable than in the rainy season. During the dry season, 36 nomadic bivouacs were found to be of four types, the cylinder and plug patterns being more frequent ( $47 \%$ and $42 \%$ respectively). In the rainy season the 52 nomadic bivouacs observed were also of the cylinder and plug types but other types, characteristic 
TABLE I - Types of bivouac locations used by $E$. burchelli and $E$. hamatum colonies at Belém region. $\mathrm{N}-\mathrm{P}=$ Nomadic Phase; $\mathrm{S}-\mathrm{P}=$ Statary Phase.

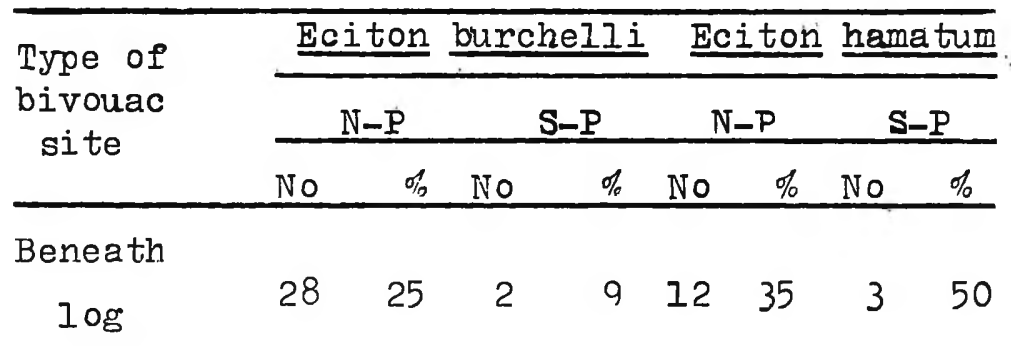

Beneath

leaves, tree but $21 \quad 18-614$ $41-$ tresses

log, tree

buttresses,ground $21 \quad 18 \quad 3 \quad 13 \quad 2 \quad 6 \quad-$ vines as

suport

Tree hol-

low

$\begin{array}{llll}7 & 6 & 14 & 61\end{array}$

Holl ow

$\begin{array}{lllllllll}\log & 37 & 32 & 4 & 17 & 6 & 18 & 3 & 50\end{array}$

TOTAI $114-23-34-6-$


TABLE II - Patterns of $E$. burchelli bivouacs in relation to colony condition and season. $\mathrm{N}-\mathrm{P}=$ Nomadic Phase; $\mathrm{S}-\mathrm{P}=$ Statary Phase.

\begin{tabular}{|c|c|c|c|c|c|c|c|c|}
\hline \multirow{3}{*}{$\begin{array}{c}\text { Bivouac } \\
\text { Type }\end{array}$} & \multicolumn{4}{|c|}{ Dry Season } & \multicolumn{4}{|c|}{ Rainy Season } \\
\hline & \multicolumn{2}{|c|}{$\mathrm{N}-\mathrm{P}$} & \multicolumn{2}{|c|}{$S-P$} & \multicolumn{2}{|c|}{$\mathrm{N}-\mathrm{P}$} & \multicolumn{2}{|c|}{ S-P } \\
\hline & No & $\%$ & No & $\%$ & No & $\%$ & No & $\%$ \\
\hline Cylinder & 17 & 47 & - & - & 18 & 35 & I & 7 \\
\hline Plug & 15 & 42 & 14 & 100 & 22 & 42 & $\varepsilon$ & 57 \\
\hline Curtain & 3 & 8 & - & - & 3 & 6 & I & 7 \\
\hline Compound & - & - & - & - & 7 & 13 & - & - \\
\hline Pouch & 1 & 3 & 一 & - & 2 & 4 & $\angle$ & 29 \\
\hline TOTAI & 36 & - & 14 & - & 52 & - & I & - \\
\hline
\end{tabular}


TABLE III - Patterns of E. hamatum bivouacs in relations to colony conditions. $\mathrm{N}-\mathrm{P}=$ Nomadic Phase; $\mathrm{S}-\mathrm{P}=$ Statary Phase.

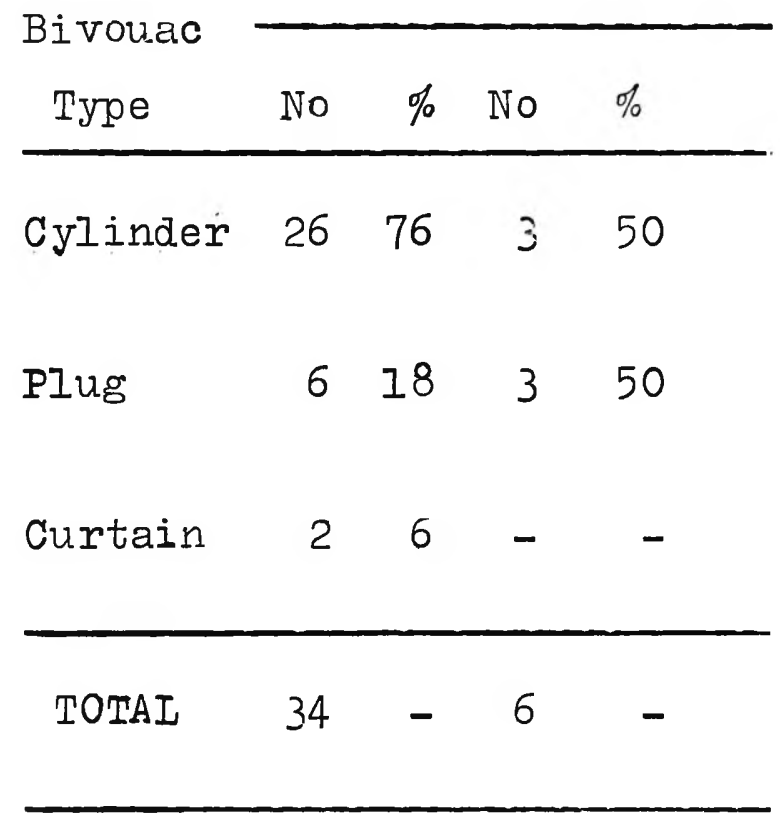

of more exposed sites were also recorded: the curtain $(6 \%)$, compound (13\%) and pouch types $(4 \%)$. The more drastic difference between the bivouac patterns in the dry and rainy seasons showed up in the statary bivouac. Table II shows that during the dry season the bivouacs are only of the plug pattern; in the rainy season 5 types were recorded the plug $(37 \%)$ and pouch $(29 \%)$ being the more frequent ones.

The bivouac patterns described by Schneirla are, of course, intimately related From Table III it is ascertained that in this case there are only three nomadic bivouac types, and all of them form the cylinder pattern. In the statary phase only the plug and cylinder types appear. Unfortunately bivouac records were gathered for this species only during the rainy season.

The bivouac patterns described by Schneirla are, of course, intimately related to the conditions of the bivouac location sites and consequently with the degree of exposure of the bivouacs. Following Schneirla, Brown and Brown (1954) and Schneirla (1971) the exposure of the bivouacs is related to colonial conditions. They also showed the nomadic bivouacs to be more exposed than the statary ones.

During the nomadic phase, a variation in the exposure degree and patterns in relation to the stage of larval development was observed in Belém. Table IV shows that in the first nomadic days the curtain and compound types (more exposed bivouacs) are recorded while in the last nomadic days the plug bivouac (sheltered bivouac) is more frequent. It seems that when the colony has mature larvae, 
there is a need of increased protection and so the establishment of the bivouacs occurred at more sheltered locations. The same was observed for $E$. hamatum. The cylinder (frequentely exposed) and curtain bivouac are more frequent in the first nomadic days than the plug pattern (See Table V).

\section{c. Elevated bivouacs}

The most striking difference concerning bivouac locations among Ecitonini species is their position in relation to ground level. The bivouacs of Labidus praedator, Labidus coecus, Neivamyrmex sp, E. rapax, E. vagans, etc. for example, are almost never exposed above the ground surface. The $E$. hamatum and $E$. burchelli are called "terrestrial species" because the establishment of their nests and daily raids take place practically on the ground level. These species extend their raid columns among the lower and higher vegetation, so the bivouac is not infrequently established in an elevated position.

Table VI shows that $E$. burchelli colonies formed more elevated bivouacs (nomad and statary) than E. hamatum. The same table shows that for $E$. hamatum bivouacs above 1 meter were never recorded and that a greater percentage of elevated bivouacs was recorded in the statary phase $(17 \%)$ than in the nomadic one. Considering all nomadic and statary bivouacs together (12 bivouacs) only one was formed above the ground level. For E. burchelli the data of Table VI demonstrate the statary bivouacs to be almost entirely formed above the ground level, since of 23 statary bivouacs, $83 \%$ were in elevated locations, and frequently above 1 meter. In the nomadic phase the establishment of the bivouacs occurs frequently on the ground ( $86 \%$ in 114 bivouac records). Elevated bivouacs below and above 1 meter $(14 \%)$ also occur. The data shows that the colonies of $E$.

Table IV - Bivouac patterns of five Eciton burchelli colonies in relation to the nomadic days.

\begin{tabular}{|c|c|c|c|c|c|c|c|c|c|c|c|}
\hline \multirow{3}{*}{$\begin{array}{l}\text { NOMADIC } \\
\text { DAYS }\end{array}$} & \multicolumn{10}{|c|}{ FREQUENCY OF BIVOUAC PATTERNS } & \multirow{3}{*}{ TOTAL } \\
\hline & \multicolumn{2}{|c|}{ Cylinder } & \multicolumn{2}{|c|}{ PIug } & \multicolumn{2}{|c|}{ Pouch } & \multicolumn{2}{|c|}{ Comp ound } & \multicolumn{2}{|c|}{ Curtain } & \\
\hline & No & $\%$ & No & $\%$ & Nio & $\%$ & No & $\%$ & ivo & $\%$ & \\
\hline $10-30$ & 12 & 54 & 8 & 36 & - & - & 1 & 4 & 1 & 4 & 22 \\
\hline $40-6 \div$ & 9 & 56 & 4 & 25 & 1 & 6 & $I$ & 6 & 1 & 6 & 16 \\
\hline $70-90$ & 8 & 33 & 11 & 46 & - & - & 2 & 8 & 3 & 13 & 24 \\
\hline $100-120$ & 5 & 29 & 7 & 41 & 1 & 6 & 3 & 18 & $I$ & 6 & 17 \\
\hline $130-150$ & 1 & 17 & 4 & 67 & 1 & 17 & - & - & - & - & 6 \\
\hline $160-180$ & - & - & 3 & 100 & - & - & - & - & - & - & 3 \\
\hline TOTAI & 35 & 40 & 37 & 42 & 3 & 3 & 7 & 8 & 6 & 7 & 88 \\
\hline
\end{tabular}


Table V - Pattern of bivouacs during two Nomadic phase of E. hamatum colony $(E-7)$ in relation the nomadic days.

FREQUENCY OF BIVOUAC PATTERNS

Nomadic TOTAL

Days C.ylinder Plug Curtain

\begin{tabular}{|c|c|c|c|c|c|c|c|}
\hline & No & $\%$ & No & $\%$ & No & $\%$ & \\
\hline $10-20$ & 3 & 75 & & 25 & - & - & 4 \\
\hline $30-40$ & 3 & 75 & - & - & 1 & 25 & 4 \\
\hline $50-60$ & 4 & 100 & - & - & - & - & 4 \\
\hline $70-80$ & 4 & 100 & - & - & - & - & 4 \\
\hline $90-100$ & 3 & 75 & - & - & 1 & 25 & 4 \\
\hline $110-120$ & 1 & 25 & 3 & 75 & - & - & 4 \\
\hline $139-140$ & 3 & 75 & 1 & 25 & - & - & 4 \\
\hline $150-160$ & 3 & 75 & 1 & 25 & - & - & 4 \\
\hline $179-180$ & 2 & 100 & - & - & - & - & 2 \\
\hline TOTAL & 26 & 76 & 6 & 18 & 2 & 6 & 34 \\
\hline
\end{tabular}


Table VI - Frequency of elevated bivouacs in relation to $E$. hamatum and $E$. burchelli colony conditions.

\begin{tabular}{|c|c|c|c|c|c|c|c|c|}
\hline \multirow{3}{*}{ PHASE } & \multicolumn{8}{|c|}{ FREQUENCY OF ELEVATED BIVOUACS } \\
\hline & \multicolumn{3}{|c|}{ E. hamatum } & & \multicolumn{4}{|c|}{ E. burcheIIi } \\
\hline & $\begin{array}{c}\text { On } \\
\text { ground }\end{array}$ & $\begin{array}{l}\text { Below } \\
\text { Imeter }\end{array}$ & $\begin{array}{l}\text { Above } \\
\text { Imeter }\end{array}$ & $\begin{array}{l}\% \text { ele } \\
\text { vated }\end{array}$ & $\begin{array}{l}\text { On } \\
\text { ground }\end{array}$ & $\begin{array}{l}\text { Bel ow } \\
\text { lmeter }\end{array}$ & $\begin{array}{l}\text { Above } \\
\text { Imeter }\end{array}$ & $\begin{array}{l}\% \text { ele- } \\
\text { vated }\end{array}$ \\
\hline Statary & 5 & 1 & - & 17 & 4 & 4 & 15 & 83 \\
\hline Nomad & 6 & - & - & 0 & 98 & 7 & 9 & 14 \\
\hline TOTAL & 11 & 1 & - & 8 & 102 & 11 & 24 & 24 \\
\hline
\end{tabular}


burchelli have a greater tendency to establishing their bivouacs at elevated sites. This tendency of $E$. burchelli colonies is ummatched among the doryline ants. No significant differences in the frequency of elevated bivouac formation for $E$. burchelli was noted in relation to the dry and rainy seasons. During the rainy season and when the colony is in a "varzea" forest, the bivouacs are established in elevated conditions during the tide period of the Guamá River (South limit of the APEG Area). This is more evident for the statary bivouac, because the colony settles in a spot for about 20 days. The colony in statary conditions during the tide period of the Guamá River presents several secondary changes of the bivouac, with a gradual evacuation of the ants from the parts of the bivouac gradually reached by the water level. Thus the bivouac becomes elevated and it can change in form and position, e.g., the cylindrical becomes a pouch. The same was observed under the action of rain.

\section{Relative exposure of the bivouac}

The different exposure of the bivouac in relation to colony condition and season was observed by Schneirla (1933) and Schneirla, Brown and Brown (1954). These papers disclosed that statary bivouacs of $E$. hamatum and $E$. burchelli are formed in more sheltered sites, that is, beyond the protection of the mass of clustered ants enclosing the queen and brood, the statary bivouacs have frequently a physical surrounding wall.

After analyses of 114 nomadic bivouacs, of Eciton burchelli colonies in Belém, $49 \%$ were found to be exposed and $51 \%$ sheltered. In the statary condition, of 23 bivouacs $22 \%$ were exposed and $78 \%$ sheltered. For $E$. hamatum of 34 bivouacs observed $75 \%$ were exposed and $15 \%$ sheltered; of 6 bivouacs in the statary condition $33 \%$ were exposed and $67 \%$ sheltered. From the above data it seems that the $E$. hamatum bivouacs are formed in more exposed sites than the $E$. burchelli ones. If we consider however, the degree of bivouac exposure of $E$. burchelli in relation to the seasons, the results are quite different. During the dry season, $E$. burchelli colonies established 49 nomadic bivouacs and $35 \%$ were exposed and $65 \%$ sheltered; in the rainy season from 66 nomadic bivouac records $61 \%$ were exposed and $39 \%$ sheltered.

This is more evident after observing Figure 1 . During the rainy season (January to May), the frequency of exposed bivouacs is higher and gradually becomes low after June (starting of the dry season) when the sheltered bivouacs become more frequent. But the exposure condition is not merely a by-product of seasonal change. Figure 2 presents data analysing the exposure degree of 42 bivouacs in relation to the sequence of their establishment during the nomadic phases both in dry and rainy season. It can be seen that the first bivouacs are exposed; from the $6^{\text {th }}$ bivouac on, the exposure degree decreased. It was observed however, that during a nomadic phase of $E$. burchelli, the colony migrations could not occur daily. Therefore, the bivouac durations must be longer than 24 hours and the number of bivouacs established is less than the nomadic days. Considering the exposure degree of the bivouac in relation to the nomadic day, it can be seen in Figure 3 that from the $3^{\text {rd }}$ to $10^{\text {th }}$ nomadic day the bivouacs established are exposed; afterward the frequency of sheltered bivouacs increased. These observations are seasonally independent and probably more dependent upon brood age and queen condition. 


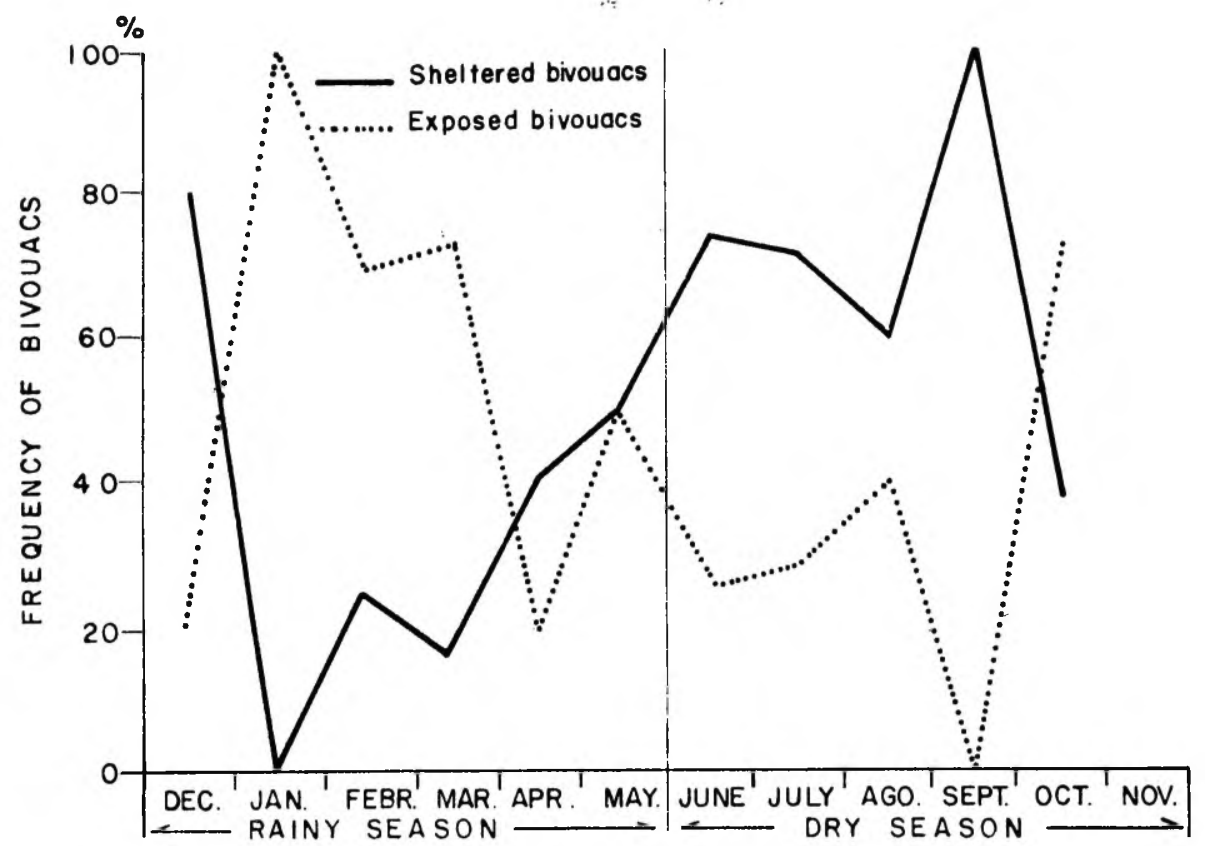

Figure 1 - Frequency $(\%)$ of sheltered and exposed nomadic bivouacs of Eciton burchelli colonies recorded during rainy and dry season of Belém region.

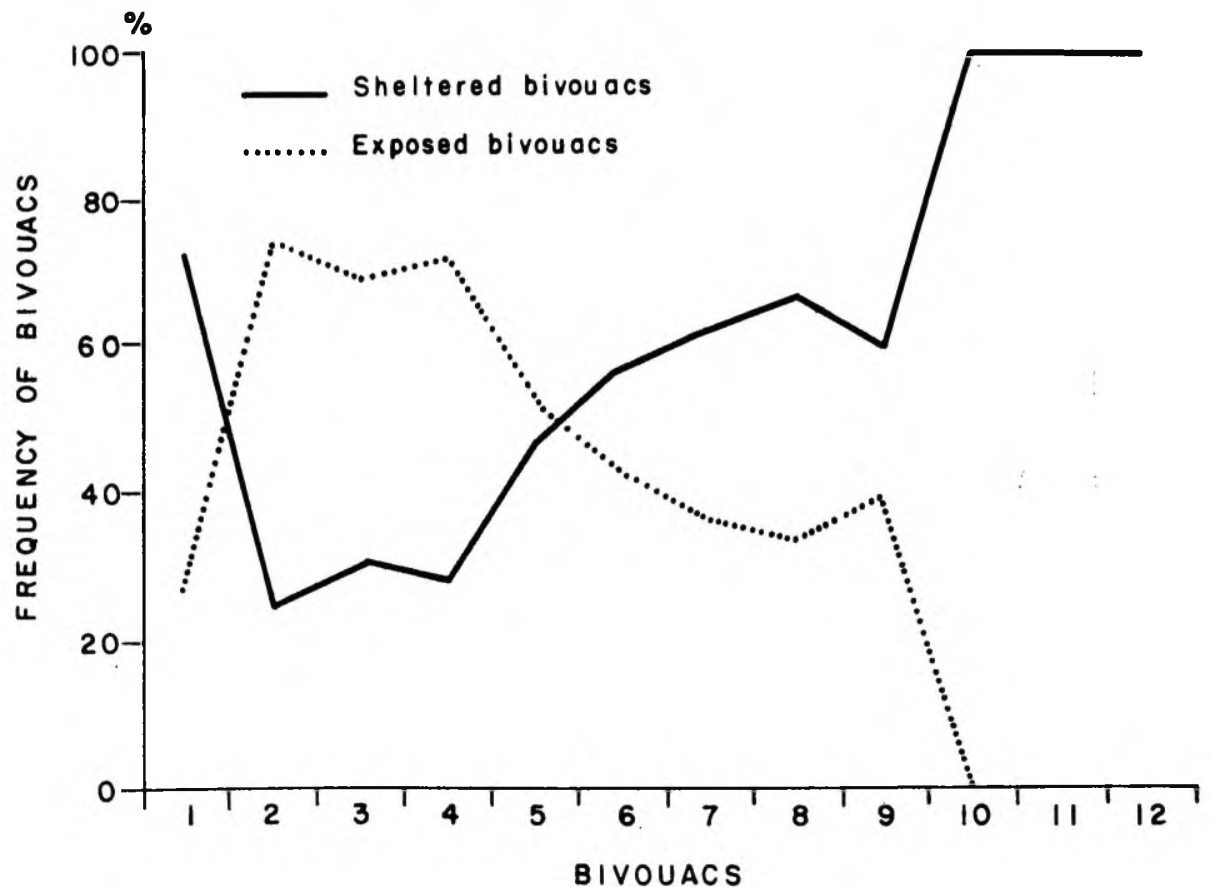

Figure 2 - Frequency (\%) of sheltered and exposed Nomadic bivouacs of $\boldsymbol{E}$. burchelli colonies in relation to the establishment sequence. 


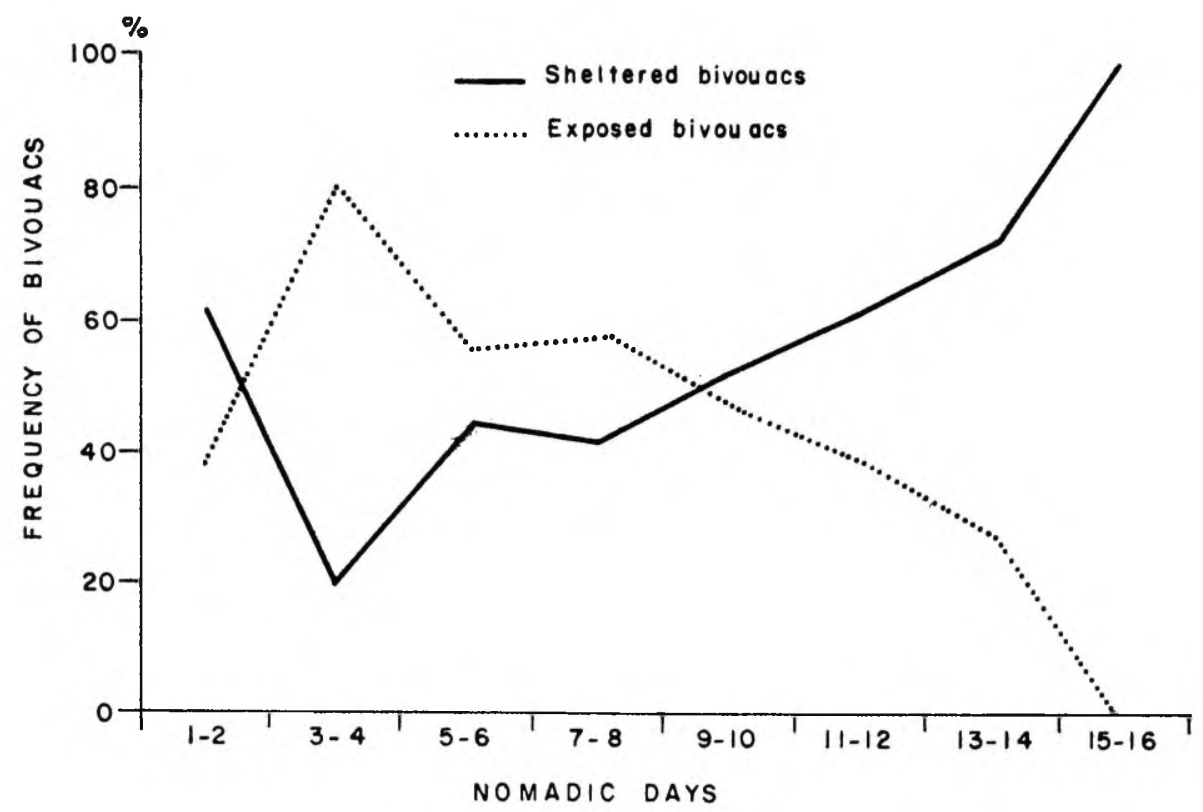

Figure 3 - Frequency (\%) of sheltered and exposed Eciton burchelli bivouacs in relation to the nomadic days.

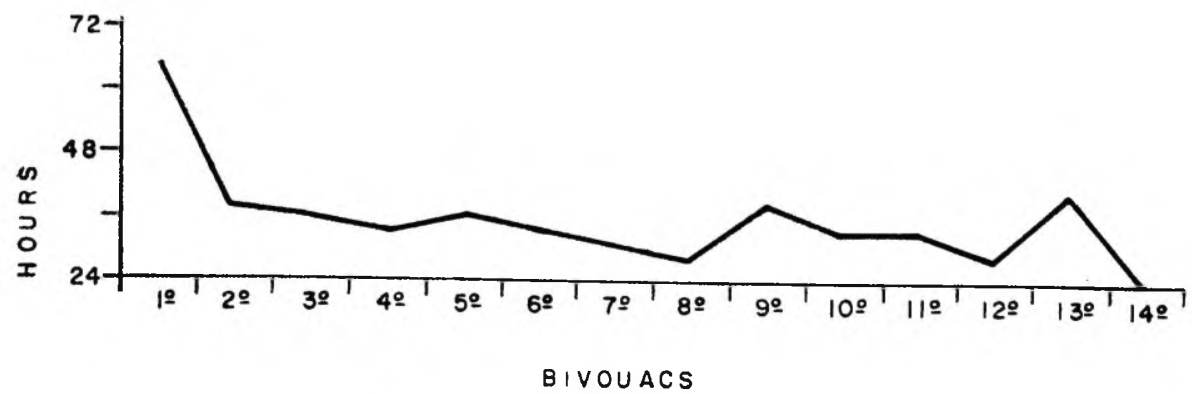

Figure 4 - Durations (hours) of the bivouacs established during the nomadic phases of five $E$. burchelli colonies in relation to the establishment sequence. 


\section{E. Duration of the bivouacs}

The duration of the nomadic bivouacs relates to the beginning and number of colony migrations during a nomadic phase, and also to the migratory activity. For $E$. hamatum colonies it was observed that the migratory activity is higher than the recorded for $E$. burchelli. In 86 nomadic days (5 nomadic phases) of an $E$. hamatum colony 86 bivouacs were recorded; then the duration of each bivouac of this colony was 24 hours. The same did not occur in E. burchelli colonies, since the colonies stay more time at the given place.

The data of $E$. burchelli colonies at Belém region showed that the first nomadic bivouacs have an enlarged duration ( 30 to 54 hours). Figure 4 shows that from the $2^{\text {nd }}$ to $14^{\text {th }}$ bivouacs, the durations decreased, being always lower than in the first bivouac. This is more evidente since in 365 nomadic days (27 nomadic phases of five colonies), $18 \%$ of the colonies spent in the first bivouacs; $12 \%$ in the second and, then the percentage gradually decreased.

Concerning bivouac durations in relation to the seasons it was found that in the rainy season the mean duration of the bivouac was 32 hours and in the dry season 29 hours, or that during the rainy season the bivouac clurations are a little longer and there is less colony migration.

The bivouac duration seems to be influenced also by the colonial division process, as ascertained by the observations on colonies E-2A and E-2B which resulted from a process of colonial division. The colony E-2A formed during 44 nomadic days ( 2 nomadic phases) 17 bivouacs, the bivouac mean duration being 54 hours. This duration is longer in the second nomadic phase after the division process, therefore in 31 days the colony presented 6 nomadic bivouacs and each one lasted 5 days. Concerning colony E-2B, in 111 nomadic days 66 bivouacs were recorded, and the mean duration of each one was 31 hours, that is, similar to the colonies.

\section{F Inter bivouacs distance}

The distance between a previous bivouac and the new one formed after finishing a raid, is equal or less than the distance length for the raid column developed by the colony during the nomadic day (Schneirla, 1944b; 1945).

In Belém the mean distance among 116 bivouacs established by three colonies was equal to 52 meters, with a variation of 10 to 180 meters. However, observing Figure 5 some considerations can be drawn concerning colony condition and distance between the bivouacs according to the establishment sequence. The figure shows that the mean distance between the statary to the first nomadic bivouac is always less than the mean distances between the other bivouacs established afterward. The mean distances between the last bivouacs are larger than in the first ones. The same figure presents the mean distances between the bivouacs formed by an $E$. hamatum colony. For this species the mean distance was higher than the recorded for $E$. burchelli, so for 86 records the mean distance was 157 meters (variation of 10 to 400 meters). In relation to the establishment sequence, as in $E$. burchelli colonies, the mean distances between the bivouacs are higher in the last bivouacs and the first nomadic bivouacs are formed near to the statary bivouac. 


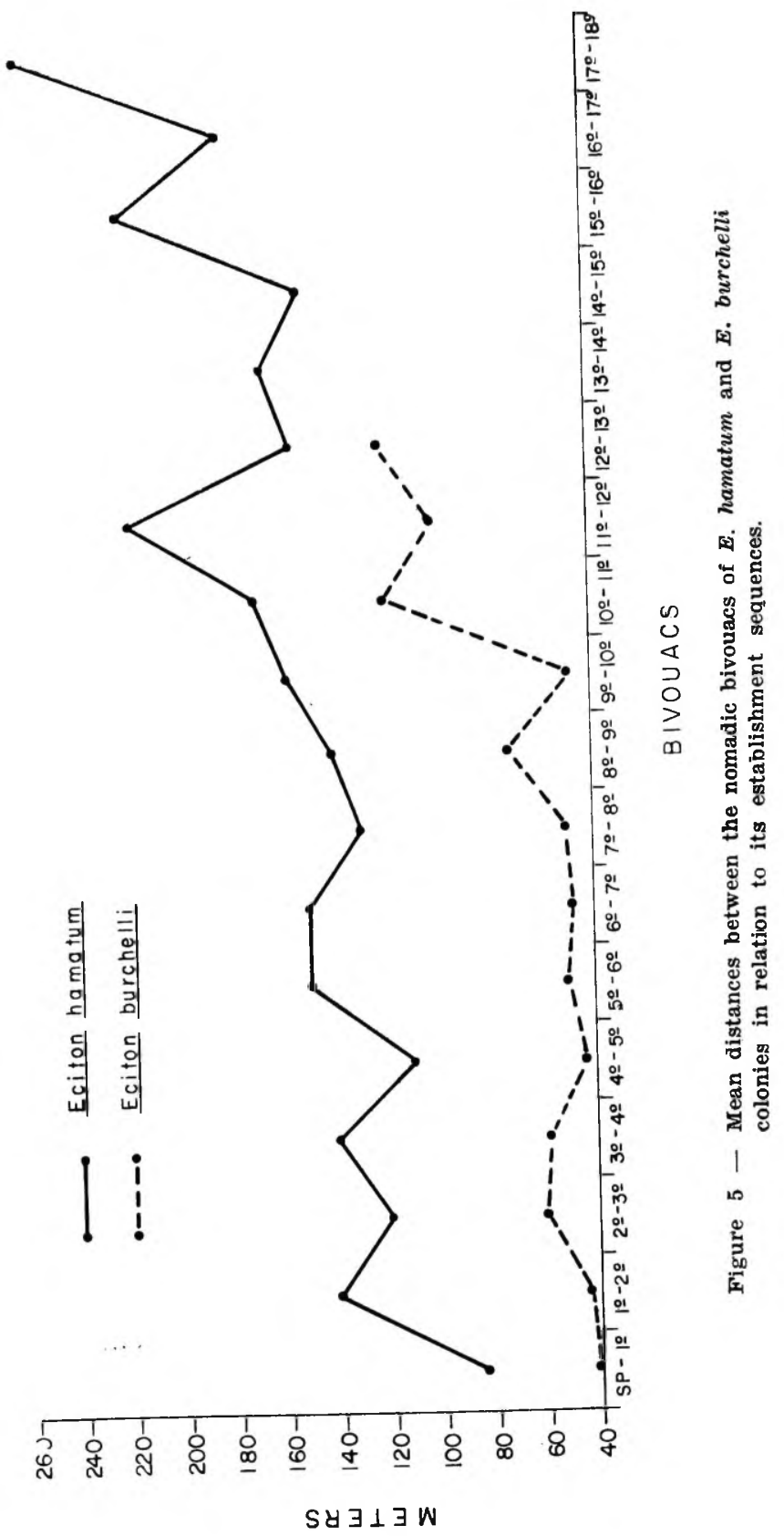




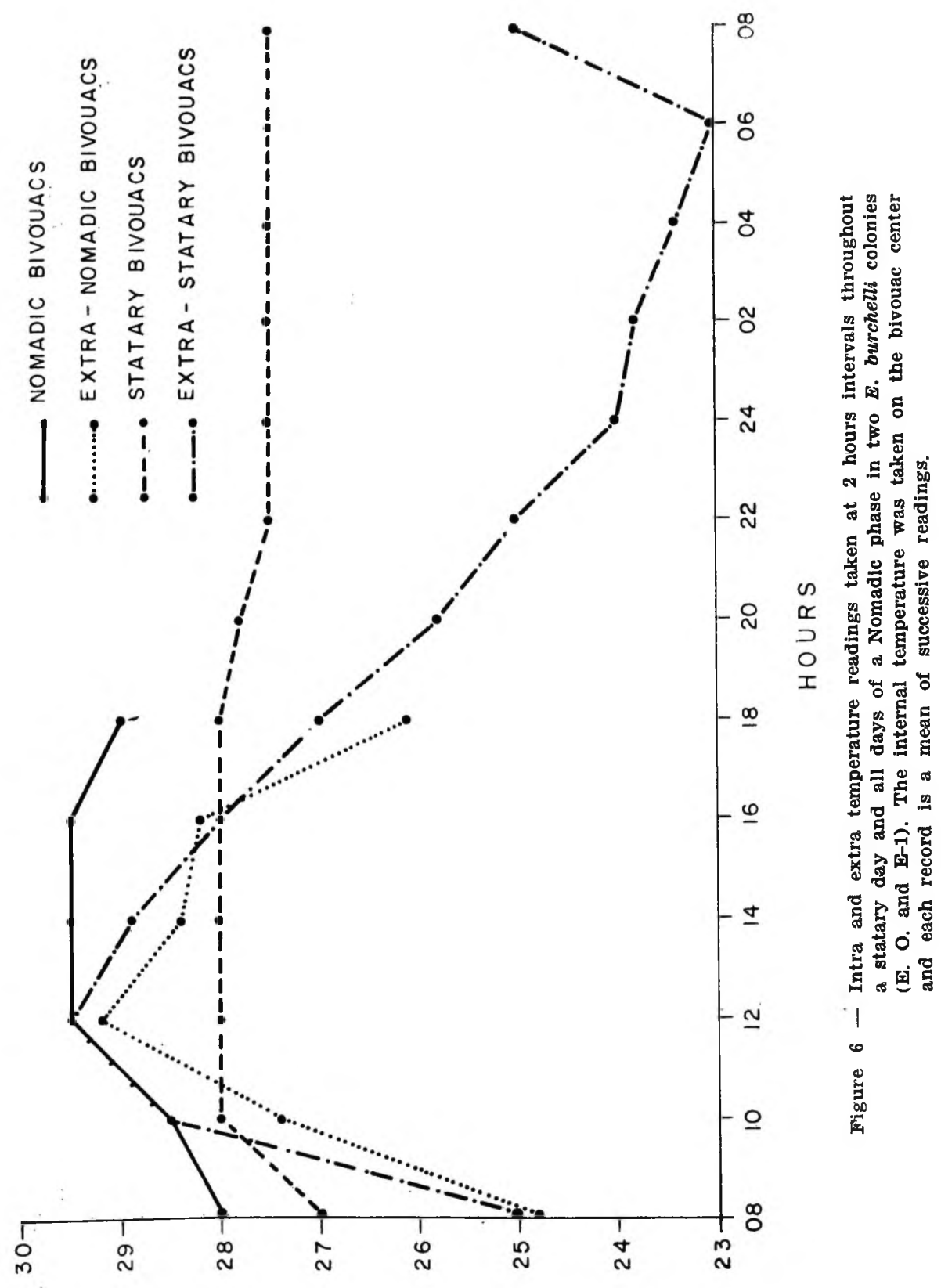

( ○) $\exists \forall \cap \perp \forall \forall \exists d W \exists \perp$ 


\section{G. The bivouac temperature}

The temperature of nomadic bivouacs was recorded during 12 days in a nomadic phase (colony E- 0 , duration of 18 days). The temperature was measured from the $5^{\text {th }}$ nomadic day on. The atmospheric temperature was $27^{\circ} \mathrm{C} \pm 4.5^{\circ} \mathrm{C}$ (51 readings) while the central part of the bivouac presented $28.6 \pm 2.6^{\circ} \mathrm{C}$.

Considering the nomadic bivouac mean temperature in relation to the time of the day, Figure 6 shows that the temperature of the central part of the bivouac is more constant than the environmental one, so that in the interval of 08-12 hours a.m. the fluctuation was $5^{\circ} \mathrm{C}$ while in the bivouac temperature the variation was only $1.5^{\circ} \mathrm{C}$.

The extra and intra temperature data of a statary bivouac is presented in the same figure. The bivouac temperature changed from $27^{\circ} \mathrm{C}$ ( 6 hours a.m.) to $28^{\circ} \mathrm{C}$ (12 hours a.m.) while the extra bivouac temperature presented a variation from $23^{\circ} \mathrm{C}$ ( 6 hours) to $29.5^{\circ} \mathrm{C}$ (12 hours a.m.). The intra bivouac temperature during the statary period remained constant irrespectively of the fluctuation of ambient temperature; the most critical periods for colony seems to be between 8 to 12 a.m. hour and 8 p.m. to 6 a.m. In the first interval the ambient temperature increased $4^{\circ} \mathrm{C}$ and dropped $3^{\circ} \mathrm{C}$ in the second. In these periods the intra bivouac temperature varied only $1^{\circ} \mathrm{C}$ which demonstrates the capacity of the colony in controlling efficiently its microclimate.

Concerning the nomadic bivouac, the temperature of the statary is less variable and remained constant during the critical periods.

\section{DISCUSSION}

The army ants of Neotropical and Paleotropical region have retained primitive carnivorous dietary characteristics based on predatory foraging activities and have developed reproductive capacities supporting large colonies and a nomadic way of life cycle. The nomadic way of life cycle is considered by several authors (Wilson 1958a, 1971; Wheeler 1910, 1936) as the main character for the biological success of the Dorylinae and Ecitoninae in relation to other ants of the "poneroid complex" (Brown, 1954), such as in relation to the species of the genera Leptogenys, Phyracaceas and Simopelta. These ants, known as legionary ants, have a nomadic group predatism behavior and somewhat large colonies. According to Wheeler (1928) and Wilson (1958a; 1971) the nomadic colony is essential for a social insect to maintain a carnivorous diet since this would be practically impossible if the colonies had a permanent nesting site. The above authors and also Schneirla, Brown and Brown (1954) agree that the changes in the nesting site were enforced by depletion of food in the occupied area. So the temporary nest or bivouac is a key factor in the adaptive pattern of the army ants to the carnivorous habits and nomadic way of life and conversely the study of the bivouacs are of major importance in understanding the behavior of the army ants and also their evolution.

A detailed discussion of the formation and internal composition of bivouacs has been published by Schneirla (1933, 1949b, 1971), Schneirla, Brown and Brown (1954) and Rettenmeyer (1963). Following Schneirla (1971) the bivouac of all army ants has four main roles. It serves as a base and center of operation for 
the colony. This is obvious when the colony is in a nomadic phase when each new nest gives the colony the advantage of invading other areas and capturing buoty. In this aspect it is important to consider the number of bivouacs established and the diversity of booty captured by the species. In the course of the present study $E$. hamatum established as many bivouacs as the number of nomadic days, and so the colony migrates daily. The data collected agree with that of previous authors evidencing that $E$. hamatum colonies attacked more wasp nests of the genera Polybia and Polistes and some ants, while E. burchelli captured the most variable booty types, attacking several Arthropoda species and some Vertebrates. This, of course, is related with the ditferent raid pattern of the two species, that is, column raid for $E$. hamatum and swarm raid for $E$. burchelli (Rettenmeyer, $1963)$. In the case of $E$. hamatum it seems that there is a necessity to change the nest site every nomadic day because the colony, in this way, will have more oportunities in the new site to capture the specific booties. This is reinforced also by the raid column lengths and by the distance between the bivouacs that are longer than in $E$. burchelli. Then, for $E$. hamatum the daily changes of the center of operation (bivouac) give the colony more advantages than for $E$. burchelli. The distances of the raid columns, between the bivouacs and the number of migrations are, of course, related to the internal conditions of the colony (relation of the workers with the broods and queen, etc.).

A second role of the bivouac pointed by Schneirla (1971) is that the bivouac is a shelter for the colony. The clustered ants around the brood and queen increase the protection against predators (coatimundis, ant-eaters) and also provides a physical shelter against climatic variations giving the colony an homogeneous internal microclimate.

The observations of Schneirla, Brown and Brown (1954) and Jackson (1957) and also the present data suggest that the bivouac sites are not chosen at random. The present data show there is a tendency for the colonies of $E$. burchelli and $E$. hamatum to establish the bivouacs on certain locations. In these sites the ants probably capture the most of booties and therefore, they are guided to stay in places by their preys. This is reinforced by the greater variation found in the location types of nomadic bivouacs than in statary phase. In $E$. burchelli the 23 observed statary bivouacs were established on four locations in which tree hollows and hollow logs were the most frequent and the establishment of the nomadic bivouacs occur in 5 different types of sites. The same was observed for $E$. hamatum colonies. By comparing the records of the location types of $E$. burchelli bivouacs with those of $E$. hamatum it is evident that in the first there is more variation and this agrees with the diversity of site inspected by $E$. burchelli colonies during the raid activities. The data for the same species obtained at Barro Colorado by Schneirla et al. (1954) demonstrated the same. These authors recorded the temperature and relative humidity of bivouac sites and verified that the sites more used by the colonies have a more stable microclimate than the control (more exposed site). They also verified that the sites of statary bivouacs have a more stable relative humidity than those of nomadic bivouacs.

According to these locations there are several ways in which the cluster of ant bodies hangs from supporting structure to the ground. Then the bivouac patterns described by Schneirla et al. (1954) are related with the types of esta- 
blishment locations and their microclimate and they reflect an adjustment of the bivouac as a shelter.

In the $E$. burchelli colonies in the Belém area a variation in bivouac patterns was recorded according to the season and colony condition. It was observed that during the dry season the most frequent nomadic bivouac type is the cylinder (47\%) and plug $(42 \%)$ patterns, which are the types of more sheltered bivouacs. Schneirla, Brown and Brown (1954) observed this for the same species also recording that in 151 bivouacs, $46 \%$ were cylinder and $11 \%$ plug; in the rainy season they observed that the most frequent types are the cylinder $(50 \%)$ and pouch $(19 \%)$, frequently more exposed bivouacs. The statary bivouacs presented the same changes. During the dry season in Belém the $E$. burchelli colonies established only plug bivouacs while in the rainy season we recorded five types of bivouacs located in more exposed sites (curtain, pouch and compound types).

By comparing the nomadic and statary bivouacs the patterns presented are seen as an adaptation to the colony condition also. The statary bivouacs are established in more sheltered places (Table I and II). In Table I, of 23 statary bivouacs $61 \%$ are established in tree hollows, and in table II, even in the rainy season, the more frequent pattern is the plug bivouac, that is, a more protected bivouac. So, according to the statary or nomadic condition, the bivouacs are established in more protected or open places. In accordance to brood developmental stage and queen condition, the colony responses are different. Our data evidenced that when the colony has pupae, eggs, small larvae and physogastric queen (statary period), there is a need for increased protection as reflected by the types of sites and patterns of the bivouacs.

In the nomadic period the bivouacs are more exposed but there is variation according to the nomadic days or larval age. Table IV evidences that more exposed bivouac patterns (compound, curtain, pouch) occurred from the first to the $10^{\text {th }}$ $12^{\text {th }}$ nomadic days. After the $10^{\text {th }}$ nomadic day the plug pattern in predominant and then, when the larvae attained the maturity stage, there is a need of more protection and there are responses of the adult workers for this. The same is observed (Table V) for the E. hamatum colony. This was already suggested by Schneirla in his papers but he presented no quantitative data to support his idea.

Other records demonstrating the role of the bivouacs as shelter places concern the exposure degree of the bivouacs in relation to seasons and colony condition. Figure 1 demonstrates that there are responses of the colony, during the nomadic period, to drier or humid weather, by establishing bivouacs more or less exposed. Schneirla, Brown and Brown (1954) observed the same, recording during the dry season in 152 nomadic bivouacs of $E$. burchelli $70 \%$ of exposed bivouacs and $82 \%$ in the rainy season. For $E$. hamatum nomadic bivouacs the authors verified the same decreasing of exposed bivouac during the rainy season.

The degree of exposure is related not only to the seasons but also to the colony condition. The statary bivouacs are less exposed than the nomadic ones. However, observing the degree of exposure of the bivouac along the nomadic phase, as shown in Figures 2 and 3, the exposure is modified according to the beginning and ending of the phase. As the nomadic colony presents only larval brood in development we conclude that this different degree of exposure may be 
related with larval age. This was found also in relation with the bivouac pattern data. The fact demonstrates that there are intense contact of adult workers with the larvae and the workers modify their behavior according to the brood changes, to provide a good condition to larval development. In all studied colonies it was observed that when the colony established the first nomadic bivouac, it contained brood in pupal development (small pupae) and it is observed in Figure 2 and 3 the greater percentage of sheltered bivouacs; then, we can conclude that with brood in pupal development the bivouacs are less exposed irrespective of the nomadic activity.

Other data demonstrating the shelter function of the bivouacs are the establishment of them in elevated sites. Schneirla (1971) found that elevated bivouacs are more frequent during the dry season. He observed also that $E$. burchelli established more elevated bivouacs than $E$. hamatum and he relates this with $E$. burchelli more frequently in higher vegetation during the nomadic period than E. hamatum. Table VI shows that indeed $E$. burchelli colonies established more elevated bivouacs $(24 \%)$ than E. hamatum $(8 \%)$; it is however, in the statary condition that we found a lager percentage of elevated bivouacs $(83 \%)$ for $E$. burchelli and $17 \%$ for $E$. hamatum. We do not agree with Schneirla that $E$. burchelli raids more frequently than $E$. hamatum on higher vegetation since we observed that $E$. hamatum frequently raids in higher places and through tree tops several times the colonies crossed streams about 5 meters wide, very common in varzea forest. However, we never found bivouacs of this species established above 1 meter as in $E$. burchelli. Schneirla observed also underground bivouacs that are more frequent under dry weather. It seems that the bivouac establishment level may depend upon the colony and weather condition. In Belém we found no underground bivouac what may be due to the climate patterns of Amazonian forest that shows a less drastic dry season than that of Barro Colorado Island.

The bivouac is also an incubator for the brood. Schneirla et al. (1954) and Jackson (1957) demonstrated that according to the position of the brood in the bivouac the temperature and humidity are more or less variable. They also verified that there is temperature and humidity control in the internal environment of the bivouac. They recorded that while the external temperature changed about $7^{\circ} \mathrm{C}$ along the day, the bivouac temperature change only $3^{\circ} \mathrm{C}$. Comparable intrabivouac control was observed for humidity. The same was observed by us (Figure 7).

This temperature and humidity control, according to Schneirla (1971), is based on properties of the ants. Schneirla gives an example of environmental control: as the forest air cools late at night, ants hooked in the bivouac wall draw closer together while others move between spaces in the wall. Through these actions the ants thicken and tighten their wall so that internal heat is preserved and cool air is shut out. Another control refers to the circulation of air through the bivouac. This is more easy to observe during the raiding when the bivouac wall become more porous permiting the circulation of air, increasing internal evaporation and elimination of the gaseous wastes.

The data about bivouac durations and distances between the nomadic bivouac may be related with the colony condition, raid and emigration activities. The 
bivouac durations of $E$. burchelli nomadic colonies, as shown in Figure 4, changed according to the nomadic activity development. According to Schneirla (1971), with the development of the larval brood, there is an increase of their stimuli upon the adult workers and the colony excitation is high. Near the end of the nomadic phase the excitation is higher, the ants attack more prey, the raiding is more vigorous. The excitation level and vigorous raiding, according to Schneirla, are prerequisites to migration. Then, the duration of each established bivouac reflects the level of the excitatory effects (chemical and chemiotactual) that exist in the interactions between the adult workers and larval brood. According to the higher or lower stimulation, the adult worker behavior modifies and the bivouac duration may be a response to the internal condition of the colony. We have observed (Figure 4 ) that the first bivouacs of $E$. burchelli have a longer duration than the following ones. In this species, as already said, the colony has brood in pupal development that emerges in the following nomadic days (until the $6^{\circ}$ nomadic day, Teles da Silva, 1972). The colony may stay 3 or more days in the same site and the greater part of the pupae emerge in this period. We observed also in samples of the first migration column of a colony, a great number of eggs that probably will eclode in the subsequent nomadic days. This reflects that in the first nomadic day the colony excitation did not attain a sufficient level to promote emigratory activity because the colony has pupae to emerge and eggs to eclode. The reduction in the duration of the following nomadic bivouacs demonstrated an increase of the stimuli on the adult workers caused by more larval broods and more callow workers emerging. For $E$. hamatum we did not observe this because the colonies did not present in the first nomadic days pupal broods as we observed in $E$. burchelli. The $E$. hamatum bivouacs of the studied colony have since the first to the last bivouac, the same duration of 24 hours, and then, we observed migration in all nomadic days. This difference between the two species may be on account of the colony size, E. hamatum colonies being smaller than those of $E$. burchelli. According to Schneirla (1971) in E. hamatum colonies chemical and chemicotactual stimulation are transmited among the adult workers more quickly than in $E$. burchelli. He suggested that the interactions between adult and brood in $E$. burchelli colonies are more complex than in $E$. hamatum.

The records of the distances between the nomadic bivouacs constitute another data reflecting the excitatory colony level during the nomadic phase. Figure 5 presents the mean distances between 116 bivouacs (19 nomadic phase) of $3 \mathrm{E}$. burchelli colonies E-1 (12 nomadic phase), E-2 (4 nomadic phase) and E-14 (3 nomadic phase), and 86 bivouacs of an $E$. hamatum (E-7, 5 nomadic phase). The mean distance between statary bivouacs to the first nomadic bivouac in both species is always less than other distances. During 3 nomadic phases of an $E$. hamatum colony (colony 46H-B) Schneirla (1949) observed the same. For $E$. burchelli he suggested the same but did not present quantitative data on migration distances. Figure 5 shows that the mean distances between the $E$. burchelli bivouacs tend to increase after the first bivouacs. In the same Figure we also observed that for $E$, hamatum the distances among the bivouacs are higher than in $E$. burchelli.

During the rainy season $E$. burchelli colonies present the mean distances between the bivouacs with lower volues (between 30 to 40 meters) than those recorded during the dry season (variation of 45 to 85 meters). Schneirla et al. 
(1954) and Rettenmeyer (1963) observed the same and suggested that the migration distances may be influenced by the duration of the chemical trails established previously by the same or different colonies. These trails last longer in the dry than in the rainy season and the colonies establish more easily the raids and migration columns. By picket marking a $E$. burchelli raid column during a statary phase we disclosed the workers used many times at least part of the trail route marking. The same colony returns in the following statary phase to the same tree hollow and reused the same route marking during the raid activities. Or then, the colony used the same trail route established 35 days before.

By the records on bivouac durations and distances between them, we can conclude there is not only the influence of external factors but also the reflexes of the internal condition of the army ant colony. Or then, the permanence of the colony (bivouac duration) in a site and the distances between the bivouacs reflect the responses of the workers during the establishment of the bivouacs to stimulation from the brood and queen. This may be considered as data supporting the adaptation of the bivouacs to the condition of the colony and the behavior of the army ants.

The data presented in this paper reinforces the idea that the bivouac or temporary nest is an adaptive factor developed by army ants during their evolution. This behavior is responsible for the maintenance of the primitive carnivorous dietary characteristics based on predatory foraging activities.

\section{CONCLUSIONS}

1) The bivouacs of $E$. burchelli and $E$. hamatum differ strikingly in relation to activity phase. The nomadic bivouacs are morre exposed to the general atmosphere while the statary bivouacs tend to be more enclosed within a natural cavity.

2) There is a selection of sites in the establishment of the $E$. burchelli and $E$. hamatum bivouacs to provide a more stable microclimate. According to the establishment site there are variations in the bivouac patterns. These patterns changed according to the season and brood condition.

3 ) There is a variation in the exposure degree of $E$. burchelli bivouacs according to the season, they are more exposed in the rainy season than in dry season. For the nomadic bivouacs the exposure degree changed also according to the larval development, the first bivouacs being more exposed.

4) E. burchelli colonies established more elevated bivouacs than $E$. hamatum.

5) The duration of the nomadic bivouacs of $E$. burchelli changed along the nomadic phase and may be related with the interaction degree between adult worker and brood. The bivouac durations of $E$. hamatum colony is less than in $E$. burchelli. This may be related to the more or less quick stimuli transmission due to the difference in colony size.

6) The distances between the bivouacs of $E$. burchelli and $E$. hamatum colonies seem to be related to the interaction degree between adult workers and broods. When the larvae are more developed there are more interactions between them and the workers, and the distances between the bivouacs are larger than in the beginning of the nomadic phase. 


\section{REFERENCES}

BROWN, W. L., Jr., 1954 - Remarks on the internal phylogeny and subfamily classification of the family Formicidae. Insectes Sociaux, 1: 21-31.

JACKSON, W. B., 1957 - Microclimate patterns in the army ant bivouac. Ecology, 38: 276-285.

RETTENMEYER, C. W., 1963 - Behavioral studies of army ants. Univ. of Kansas Sci. Bull., 44: 281-465.

SCHNEIRLA, T. C., 1933 - Studies on army ants in Panama. J. Comp. Psychol., 15: 267-299.

SCHNEIRLA, T. C., 1938 - A theory of army ant behavior based upon the analysis of activities in a representative species. J. Comp. Psychol., 25: 51-90.

SCHNEIRLA, T. C., 1944 - Studies on the army ant behavior pattern: Nomadism in the swarm-raider Eciton burchelli. Proc. Amer. Philos. Soc., 87: 438-457.

SCHNEIRLA, T. C., 1945 - The army ant behavior pattern: nomad-statary relations in the swarmers and the problem of migration. Biol. Bull., 88: 166-193.

SCHNEIRLA, T. C., 1949. Army an life and behavior under dry season conditions. 3. The course of reproduction and colony behavior. Bull. Am. Mus. Nat. Hist., 94: 1-82.

SCHNEIRLA, T. C., 1971 - Army ants. A study in Social Organization. Ed. by R: Topoff. San Francisco, W. H. Freeman and Company.

SCHNEIRLA, T. C., BROWN, R. Z., \& BROWN, F. C., 1954 - The bivouac or temporary nest as an adaptive factor in certain terrestrial species of army ants. Ecol. Monogr., 24: 269-296.

TELES DA SILVA, M., 1972 - Contribuição ao estudo da Biologia de Eciton burchelli Westwood (Hymenoptera, Formicidae). Tese de Doutoramento, Faculdade de Filosofia. Ciências e Letras de Ribeirão Preto, $400 \mathrm{pp}$.

TELES DA SILVA, M. In Press. Behavior of army ant Eciton burchelli Westwood (Hymenoptera, Formicidae) at Belém region. I. Nomadic — Statary Cycles, Animal Behavior.

WHEELER, W. M., 1910 - Ants, Their Structure, Development and Behavior New York, Columbia University Press.

WHEELER, W. M., 1928 - The Social Insects, Their Origin and Evolution. New York, Harcourt Brace.

WHEELER, W. M., 1936 - Ecological relations of Ponerine and other ants to termites. Proc. Am. Acad. Arts. Sci., 71: 159-243.

WILSON, E. O., 1958 -- The beginnings of nomadic and group predatory behavior in the ponerine ants. Evolution, 12: 24-31.

WILSON, E. O., 1971 - The Insect Societies. The Belknap Press, Havard Univ. 548 pp. 